\title{
LIMITATIONS ON DEFENDANT LIABILITY FOR MISLEADING OR DECEPTIVE CONDUCT UNDER STATUTE: SOME INSIGHTS FROM NEGLIGENT MISSTATEMENT
}

\author{
ELISE BANT AND JEANNIE PATERSON*
}

\section{INTRODUCTION}

Liability for having induced another to act to their detriment on the basis of a negligent misstatement can arise under the general law through a number of different avenues. The statement may be the subject of a contractual warranty. Liability may arise extra-contractually pursuant to the common law and equitable doctrines of mistake, estoppel, misrepresentation, and, following the decision in Hedley Byrne \& Co Ltd v Heller \& Partners Ltd, ${ }^{1}$ negligent misstatement. All these claims have different elements and yield diverse remedial outcomes. In Australia, the plaintiff's first port of call will usually be statute. Section 18 of the Australian Consumer Law ('ACL'), ${ }^{2}$ formerly s 52 of the Trade Practices Act 1974 (Cth) ('TPA'), contains a broad prohibition on misleading or deceptive conduct occurring in trade or commerce. Section 18 and its associated remedial provisions ${ }^{3}$ have had a marked impact on defendant liability for misstatement in Australia. Liability under section 18 does not require any element of fault, clearly encompasses omissions and silence as well as positive statements, and opens up a 'remedial smorgasbord' 4 to the victim unparalleled at common law. It is hence rational (and correspondingly common) for plaintiffs to bring their claim arising from a negligent misstatement within the statutory regime, if not instead of, then at least in addition to, any pertinent common law claims.

The frequent concurrence of claims under the statute with their common law counterparts has given rise to some valuable judicial insights into their comparative elements, remedial

\footnotetext{
* This work forms part of an Australian Research Council Discovery Grant project DP140100767 on 'Remedies under the Australian Consumer Law and the Common Law: Evolution and Revolution'. The authors thank Holly Fairhurst, Eliza Wallace and Stephanie Murphy for their considerable assistance with this research. All errors are the authors'.

${ }^{1}$ [1964] AC 465 ('Hedley Byrne v Heller’).

2 The ACL is contained in schedule 2 of the Competition and Consumer Act 2010 (Cth) ('CCA').

${ }^{3}$ ACL ss 236, 237, 238.

${ }^{4}$ Akron Securities Ltd v Iliffe (1997) 41 NSWLR 353, 364 (Mason P).
} 
consequences and the limiting considerations in those contexts that properly restrict defendants' liability. Courts have stressed that it is the words of the section and the express purposes of the legislation rather than analogy with the common law that should guide the application of the statutory prohibition. ${ }^{5}$ This is appropriate given the status of the legislation as commonwealth law and the clearly stated purposes of the legislation as furthering consumer protection, a heady contrast to the law of torts where debates over purpose continue unresolved. ${ }^{6}$ Nonetheless, courts have found it useful to draw on the tort of deceit in assessing the proper measure of damages ${ }^{7}$ and utilise distinctions from that area to determine the boundaries of actionable loss. ${ }^{8}$ The result has been a generous approach taken to key statutory issues of factual causation and defendant scope of liability, which accords with the policy of the statute to promote 'competition and fair trading and provision for consumer protection'. 9

Yet despite the broad-ranging features of the prohibition in s 18, courts have considered that liability under the section should be subject to some limitations. As Gibbs CJ observed in Parkdale Customer Built Furniture Pty Ltd v Puxu Pty Ltd ('Puxu'):

It may have been thought that the unequal position of consumers as against the corporations which supply them with commodities justified a measure that from the point of view of the latter seems draconic, but although s. 52 is intended for the protection of consumers, it is enforceable by a trade competitor who is not a consumer ${ }^{10}$ and it is not infrequently used by one trader against a rival to protect a trade name or to prevent a passing-off. The section may have been designed to protect the weak from the powerful, but it may be used by a large and powerful corporation to restrain the activities of a smaller competitor. I am, with all respect, unable to see any reason why a section so broadly expressed and so drastic in its possible consequences should be beneficially construed ... in some loose or expanded sense. ${ }^{11}$

\footnotetext{
${ }^{5}$ Marks v GIO Australia Holdings Ltd (1998) 196 CLR 494, 510 [38] (McHugh, Hayne and Callinan JJ).

${ }^{6}$ Andrew Robertson, 'Policy-Based Reasoning in Duty of Care Cases’ (2013) 33 Legal Studies 119.

${ }^{7}$ Kizbeau Pty Ltd v WG \& B Pty Ltd (1995) 184 CLR 281, 291 (Brennan, Deane, Dawson, Gaudron and McHugh JJ); Kenny \& Good Pty Ltd v MGICA (1992) Ltd (1999) 199 CLR 413, 460-1 [129] (Kirby and Callinan JJ).

${ }^{8}$ See, eg, the approach to direct versus indirect loss in cases involving acquisition of assets, discussed below at $\mathrm{xxx}$ and $\mathrm{xxx}$.

${ }^{9}$ CCA s 2.

${ }^{10}$ Reg. v. Federal Court of Australia; Ex parte Pilkington A.C.I. (Operations) Pty Ltd (1978) 142 CLR 113, esp at 120-1, 128.
}

${ }^{11}$ (1982) 149 CLR 191, 197-8 (Gibbs CJ). 
Compared to deceit, the other common law causes of action that may function in aid of consumer protection have received relatively little consideration as sources of insight into the nature of cognate statutory liability. In particular, although frequently mentioned as an analogous source of common law liability, ${ }^{12}$ the tort of negligent misstatement has received very little sustained analysis as an interpretive source for the operation of section 18 and related remedial provisions. This is a pity. In negligent misstatement, the search for appropriate defining criteria for defendant liability has identified a range of principles and standards that assist courts in the complex, multifactorial inquiry into the respective degrees of fault and responsibility of the parties that serve to delimit defendant liability. ${ }^{13}$

The aim of this article is to explore some of the potential lessons to be learned about the proper limits on defendant liability for misleading or deceptive conduct from the law of negligent misstatement. It is clearly inappropriate to interpret a statutory prohibition solely by reference to analogous common law concepts. However, common law concepts developed in the context of the tort of negligent misstatement can enlighten and inform difficult debates about the scope of statutory liability. The enquiry in this paper reveals that, although there remain some areas where the common law action is not a good 'fit' with the statutory language and purpose, there exists a number of instances where concepts developed in the context of the tort of negligent misstatement have the potential properly to influence the extent of statutory liability.

\section{LIMITING FACTORS IN THE LAW OF NEGLIGENT MisstATEMENT}

\section{A Reasonable Foreseeability is Necessary but not Sufficient}

Under the common law, one way of limiting defendant liability is to restrict the circumstances in which a duty of care will arise. In the seminal case of Hedley Byrne v Heller, ${ }^{14}$ the various members of the court framed this question in the context of negligent misstatement somewhat differently. However, all were agreed that reasonable foreseeability of harm, central in establishing a duty of care in negligence cases involving physical damage, is simply not

\footnotetext{
12 See, eg, (2001) 206 CLR 459, 470 [19] (Gleeson CJ) and the discussion in Havyn Pty Ltd $v$ Webster (2005) ASAL ๆ55-143, 60 077-8 [117] (Santow JA, Tobias and Brownie JJA concurring).

${ }^{13}$ Perre v Apand Pty Ltd (1999) 198 CLR 180, 220 [105] (McHugh J); Travel Compensation Fund v Tambree (2005) 224 CLR 627, 646 [56] (Kirby J).
} 
sufficient to establish a duty in negligent misstatement. ${ }^{15}$ This conclusion has been endorsed multiple times by the High Court of Australia. ${ }^{16}$

There are two main policy factors identified in the case law that are said to support this conclusion. The first arises from the inherent tendency of statements to be circulated well beyond their original and intended audience, to be put to use in ways outside their original purpose and to produce purely economic losses. ${ }^{17}$ These factors raise 'the law's concern to avoid the imposition of liability "in an indeterminate amount for an indeterminate time to an indeterminate class". ${ }^{18}$ A second policy concern is that a blanket duty to take reasonable care to avoid causing foreseeable economic loss would run counter to important norms of commercial responsibility ${ }^{19}$ and impose a correspondingly heavy burden on party autonomy. ${ }^{20}$ Here it should be recognised that there are competing considerations. Misinformation can distort the market and lead to an inefficient allocation of resources. Thus, it is legitimate to encourage parties to verify the accuracy of their statements and to qualify matters of uncertainty. ${ }^{21}$ Parties in the market have the freedom to pursue their own commercial interests but not always to the extent that their own failure to take care misleads those with whom they

\footnotetext{
${ }^{15}$ Esanda Finance Corporation Ltd v Peat Marwick Hungerfords (1997) 188 CLR 241, 249 (Brennan CJ) ('Esanda'), discussing Hedley Byrne v Heller [1964] AC 465.

${ }^{16}$ See, eg, Caltex Oil (Australia) Pty Ltd v The Dredge "Willemstad” (1976) 136 CLR 529, 573-4 (Stephen J) ('Caltex Oil'); San Sebastian Pty Ltd v The Minister (1986) 162 CLR 340, 353-4 (Gibbs CJ, Mason, Wilson and Dawson JJ), 367 (Brennan J) ('San Sebastian'); Hill v Van Erp (1997) 188 CLR 159, 169-70 (Brennan CJ), 174 (Dawson J), 201 (McHugh J); Perre v Apand Pty Ltd (1999) 198 CLR 180, 194 [10] (Gleeson CJ), 197-8 [26][27] (Gaudron J), 217 [94] (McHugh J).

${ }^{17}$ American Law Institute, Restatement (Second) of the Law of Torts (1977) vol 3, § 552, cited in L Shaddock \& Associates Pty Ltd v Parramatta City Council [No 1] (1981) 150 CLR 225, 250 (Mason J, Aickin J concurring), see also 231 (Gibbs CJ). See also Sutherland Shire Council v Heyman (1985) 157 CLR 424, 465 (Mason J); San Sebastian (1986) 162 CLR 340, 353-4 (Gibbs CJ, Mason, Wilson and Dawson JJ), 367 (Brennan J); Bryan v Maloney (1995) 182 CLR 609, 618 (Mason CJ, Deane and Gaudron JJ), 632 (Brennan J); Hill v Van Erp (1997) 188 CLR 159, 171 (Brennan CJ), 179 (Dawson J), 192 (Gaudron J), 216 (McHugh J), 235 (Gummow J).
}

${ }^{18}$ Bryan v Maloney (1995) 182 CLR 609, 618 (Mason CJ, Deane and Gaudron JJ), citing Ultramares Corporation v Touche, 255 NY 170, 179 (Cardozo CJ) (1931). See also Esanda (1997) 188 CLR 241, 272 (McHugh J); Perre v Apand Pty Ltd (1999) 198 CLR 180, 199 [31] (Gaudron J), 221 [106] (McHugh J).

${ }^{19}$ See, eg, Caltex Oil (1976) 136 CLR 529, 551-2 (Gibbs J); Sutherland Shire Council v Heyman (1985) 157 CLR 424, 502-3 (Deane J); Bryan v Maloney (1995) 182 CLR 609, 618-9 (Mason CJ, Deane and Gaudron JJ); Hill v Van Erp (1997) 188 CLR 159, 184 (Dawson J), 192-3 (Gaudron J), 211 (McHugh J); Perre v Apand Pty Ltd (1999) 198 CLR 180, 200 [33] (Gaudron J), 219-20 [101]-[104], 223-5 [114]-[117] (McHugh J), 283 [279] (Kirby J).

${ }^{20}$ Perre v Apand Pty Ltd (1999) 198 CLR 180, 192 [5] (Gleeson CJ), 224 [115] (McHugh J), 287 [291] (Kirby J), 299 [329] (Hayne J). See also Bryan v Maloney (1995) 182 CLR 609, 619 (Mason CJ, Dean and Gaudron JJ); Caltex Oil (1976) 136 CLR 529, 568 (Stephen J), 591 (Mason J); Sutherland Shire Council v Heyman (1985) 157 CLR 424, 465 (Mason J); San Sebastian (1986) 162 CLR 340, 353-4 (Gibbs CJ, Mason, Wilson and Dawson JJ).

${ }^{21}$ See Anthony Duggan, Michael Bryan and Frances Hanks, Contractual Non-Disclosure (Longman Professional Publishing, 1994). 
are dealing. On the other hand, it is also important to preserve incentives for both parties to take steps to protect their own commercial interests. Commercial parties are usually expected actively to manage the risks to which they are exposed, and the level of protection they require. Courts have noted that most parties in negligent misstatement cases are engaged in deliberate transacting behaviour that is a prime context for the use of contracts to manage the inherent risks to which they are exposed. ${ }^{22}$ If the scope of defendant liability is too broadly defined then this agreed allocation of risk is disrupted and one party becomes the insurer for the other party's lack of care in verifying information relevant to its own interests. These considerations have led courts to be cautious about finding a duty of care in cases of negligent misstatement where the consequences of its recognition would unreasonably burden legitimate commercial conduct, particularly in circumstances where other mechanisms (such as contract) are available to mediate the risk to which parties in the position of the plaintiff are exposed.

What mechanisms, then, does the law of negligent misstatement employ to limit defendant liability in the face of these policy concerns? Accepting that the cases do not all speak with one voice, it is nonetheless possible to discern a number of overlapping standards deployed by courts to assess the relationship between the parties and their relative responsibility for harm suffered. These standards, and the factors used by courts to give content to them, provide flexible and context-specific tools for delineating the scope of defendant liability, both at the initial stage of establishing a duty of care and then in assessing the appropriate remedy for negligent misstatement.

\section{B The Reasonable Defendant}

We have seen that it has been consistently accepted in Australia and England that the requirement of reasonable foreseeability is not sufficient to meet the law's concerns of undue and excessive liability in cases of misstatement. That is not to say, however, that the requirement is otiose. Harm that is not reasonably foreseeable will fall outside the defendant's duty of care, just as it does in cases of negligence involving physical damage. ${ }^{23}$ The combination of circumstances indicative of a duty of care has been variously characterised. The High Court of Australia's current preference is for a 'salient features' approach which emphasises the importance of taking into account a range of relevant factors, including the

\footnotetext{
22 Perre v Apand Pty Ltd (1999) 198 CLR 180, 223-5 [114]-[117] (McHugh J).

${ }^{23}$ San Sebastian (1986) 162 CLR 340, 367, 369, 372 (Brennan J); Hill v Van Erp (1997) 188 CLR 159, 166, 174 (Brennan CJ), 189 (Toohey J), 201 (McHugh J); Perre v Apand Pty Ltd (1999) 198 CLR 180, 217 [94] (McHugh J), 299 [329] (Hayne J).
} 
foreseeability of harm, ${ }^{24}$ the impact of liability upon a defendant's commercial autonomy, ${ }^{25}$ the prospect of indeterminate liability, ${ }^{26}$ a claimant's vulnerability (a factor that operates to exclude plaintiffs who fail to take reasonable steps to protect their own interests), ${ }^{27}$ and the defendant's actual or assumed knowledge of the risk created by his conduct. ${ }^{28}$ Notwithstanding the diverse range of factors, courts consistently emphasise that 'the speaker must realize or the circumstances be such that he ought to have realized that the recipient intends to act upon the information or advice in respect of his property or of himself in connexion with some matter of business or serious consequence'. ${ }^{29}$ The objective nature of the test of knowledge coupled with the element of prediction as to likely reliance brings it very close to a restrictive test of foreseeability, albeit one which is not exhaustive of the conditions for defendant liability. The knowledge requirement reflects 'the need for caution lest a duty of care be imposed upon a party who has no appreciation of, and could not be expected to appreciate, the implications of making an error. ${ }^{30}$ Relevant factors going to this enquiry include the presence and objective terms of any request for advice or information by the plaintiff, whether the statement was in writing and publicly available, whether the defendant professed to possess skill and competence in the area, or warranted that the advice was correct, and whether the defendant invited the recipient to act in reliance on the information or advice, or intended the recipient to do so. ${ }^{31}$

As to this last indicator, the role of intention in cases of negligent misstatement has not been entirely clear. Many cases have stated that a duty of care will arise where a defendant intends to induce the plaintiff to rely on her statement in circumstances where she should realise that economic loss may be suffered if the statement is not true. ${ }^{32}$ The first element seems to take a subjective approach at the expense of the usual objective enquiry. But insight into the role of intention may be found in deceit, where the defendant's subjective intention to deceive has always offset fears of too much liability and where there has correspondingly been no

\footnotetext{
${ }^{24}$ Perre v Apand Pty Ltd (1999) 198 CLR 180, 220 [103] (McHugh J).

${ }^{25}$ Ibid 223-5 [114]-[117].

${ }^{26}$ Ibid 220-3 [106]-[113].

${ }^{27}$ Ibid 225-30 [118]-[130]. See discussion below.

${ }^{28}$ Ibid 230-1 [131]-[132].

${ }^{29}$ Mutual Life \& Citizens' Assurance Co Ltd v Evatt (1968) 122 CLR 556, 571 (Barwick CJ).

${ }^{30}$ Tepko Pty Ltd v Water Board (2001) 206 CLR 1, 17 [48] (Gleeson CJ, Gummow and Hayne JJ).

${ }^{31}$ San Sebastian (1986) 162 CLR 340, 357 (Gibbs CJ, Mason, Wilson and Dawson JJ), 372 (Brennan J).

32 Ibid 355, 357-8 (Gibbs CJ, Mason, Dawson and Wilson JJ), 371-2 (Brennan J). See also Glanzer v Shepard 233 NY 236, 241 (Cardozo J) (1922), cited in Hedley Byrne \& Co Ltd v Heller \& Partners Ltd (1964) AC 465, 488 (Lord Reid).
} 
requirement of reasonable reliance on the part of the plaintiff. As Brennan J stated in Gould v Vaggelas, 'the representor does not escape liability because the representee did not believe the representation in full. ... [T] he representee's self-induced gullibility is no defence to the representor. A knave does not escape liability because he is dealing with a fool. ${ }^{\text {, } 33}$ Similarly, in the case of negligent misstatement, where the defendant intends to cause the reliance that has in fact occurred, it may be said that it does not lie in the defendant's mouth to say that the reliance was not reasonably foreseeable, that their relationship was not sufficiently proximate or that the plaintiff's reliance was not reasonable. ${ }^{34}$ As Gibbs CJ, Mason, Wilson and Dawson JJ observed in San Sebastian Pty Ltd v The Minister, '[i]n cases where the defendant intends the statement to operate as a direct inducement to action, the reasonableness of the reliance will not be a critical factor'. ${ }^{35}$ It is to this latter point that we now turn.

\section{The Reasonable Plaintiff}

As we have seen, courts have consistently incorporated objective fault-based enquiries in determining whether a defendant held a duty of care to the plaintiff. The defendant is judged against a standard of reasonable knowledge and behaviour of someone in her position. Courts have also consistently recognised that the plaintiff's reliance or dependence on the statement must be reasonable. ${ }^{36}$ This requirement contains two discrete elements. The first is a requirement of factual causation. In most misstatement cases, the plaintiff will claim to have detrimentally changed his or her position in reliance on the statement. That is, the defendant's misstatement caused the plaintiff's decision to act and hence suffer loss: reliance signals causation. ${ }^{37}$ This purely factual question of causation is then overlaid by the courts' requirement of reasonable conduct by the plaintiff, an element that constitutes a very real

\footnotetext{
33 (1984) 157 CLR 215, 252 (Brennan J).

${ }^{34}$ Doyle v Olby (Ironmongers) Ltd [1969] 2 QB 158, 167 (Lord Denning).

35 (1986) 162 CLR 340, 358 (Gibbs CJ, Mason, Wilson and Dawson JJ). Cf Esanda (1997) 188 CLR 241, 257 (Dawson J); in the statutory context see De Bortoli Wines Pty Ltd v HIH Insurance Ltd (in liq) [2012] FCAFC 28 (15 March 2012).

${ }^{36}$ Hedley Byrne \& Co Ltd v Heller \& Partners Ltd (1964) AC 465, 486 (Lord Reid), 496, 502-3 (Lord Morris of Borth-y-Gest), 514 (Lord Hodson); Ministry of Housing and Local Government v Sharp (1970) 2 QB 223, 268 (Lord Denning MR); Scott Group Ltd v McFarlane [1978] 1 NZLR 553, 576; Mutual Life \& Citizens' Assurance Co Ltd v Evatt (1968) 122 CLR 556, 569-72 (Barwick CJ); San Sebastian (1986) 162 CLR 340,372 (Brennan J); Sutherland Shire Council v Heyman (1985) 157 CLR 424, 461-4 (Mason J); Tepko Pty Ltd v Water Board (2001) 206 CLR 1, 16-8 [47]-[51] (Gleeson CJ, Gummow and Hayne JJ), 23-4 [75]-[76] (Gaudron J). See also Esanda (1997) 188 CLR 241, 249-50 (Brennan CJ), 255-7 (Dawson J), 261, 265 (Toohey and Gaudron JJ), 273-4 (McHugh J).

${ }^{37}$ Indeed, the reliance requirement recognises and effectively responds to the particular causation issues that arise in negligent misstatement, for example the concern that that it is the plaintiff's own actions which cause the loss, see eg San Sebastian (1986) 162 CLR 340, 353 (Gibbs CJ, Mason, Wilson and Dawson JJ).
} 
normative restriction on the defendant's conditions of liability. ${ }^{38}$ In order for liability to arise, the circumstances must be such that it is reasonable in all the circumstances for the plaintiff to have accepted and acted upon the defendant's statement.

The authorities reveal that courts will look very closely at a number of factors relevant to the reasonableness of the plaintiff's reliance: whether the defendant held or purported to hold particular skill or expertise in the area the subject of the misstatement; ${ }^{39}$ what the plaintiff knew or ought to have known about the defendant's likely ability to make a careful and correct statement; ${ }^{40}$ whether the statement was made in a social setting or whether it was in response to a serious or formal request for information or advice; ${ }^{41}$ whether the plaintiff was in a position to check the veracity of the statement; ${ }^{42}$ whether the plaintiff was in the position to take other steps (such as entering into a contract) to protect himself from the risk of error in the statement; ${ }^{43}$ the comparative commercial experience of the parties ${ }^{44}$ and so on. All of these factors are very familiar from the law of estoppel, where courts are also used to determining whether a plaintiff's decision to act in reliance on a defendant's representation was reasonable. ${ }^{45}$ The High Court has recently emphasised that an informing consideration is the plaintiff's ‘vulnerability' — whether he was unable reasonably to protect himself because of 'ignorance or social, political or economic constraints'. ${ }^{46}$ McHugh $\mathrm{J}$ has suggested that

\footnotetext{
${ }^{38}$ Its impact on defendant liability by comparison to the role of contributory negligence considerations is significant, discussed below at xxx.

${ }^{39}$ Mutual Life \& Citizens' Assurance Co Ltd v Evatt (1968) 122 CLR 556, 571 (Barwick CJ); Esanda (1997) 188 CLR 241, 262, 265 (Toohey and Gaudron JJ); L Shaddock \& Associates Pty Ltd v Parramatta City Council [No 1] (1981) 150 CLR 225, 230-1 (Gibbs CJ). This is reflected in the court's different treatment of authorities, such as seen in L Shaddock \& Associates Pty Ltd v Parramatta City Council [No 1] (1981) 150 CLR 225; San Sebastian (1986) 162 CLR 340; and Tepko Pty Ltd v Water Board (2001) 206 CLR 1.

${ }^{40}$ Mutual Life \& Citizens' Assurance Co Ltd v Evatt (1970) 122 CLR 628, 646 (Lords Reid and Borth-y-Gest), preferred in L Shaddock \& Associates Pty Ltd v Parramatta City Council [No 1] (1981) 150 CLR 225.

${ }^{41}$ Mutual Life \& Citizens' Assurance Co Ltd v Evatt (1968) 122 CLR 556, 582-5 (Kitto J); Esanda (1997) 188 CLR 241, 257 (Dawson J); L Shaddock \& Associates Pty Ltd v Parramatta City Council [No 1] (1981) 150 CLR 225, 231 (Gibbs CJ), 239 (Stephen J).

${ }^{42}$ L Shaddock \& Associates Pty Ltd v Parramatta City Council [No 1] (1981) 150 CLR 225, 242-3 (Stephen J), 252 (Mason J, Aickin J concurring).

43 Perre v Apand Pty Ltd (1999) 198 CLR 180, 225-6 [118]-[120], 227-8 [123] (McHugh J).

${ }^{44}$ Mutual Life \& Citizens' Assurance Co Ltd v Evatt (1968) 122 CLR 556, 570 (Barwick CJ), 582 (Kitto J), cited in Chew v Amanatidis [2009] SASC 334 (3 November 2009) [39]-[40] (Gray J), see also [10], [21], [42] (Gray J). See also Tepko Pty Ltd v Water Board (2001) 206 CLR 1, 17 [49] (Gleeson CJ, Gummow and Hayne JJ), 26 [87] (Kirby and Callinan JJ).

${ }^{45}$ E Bant and M Bryan, 'Fact, Future and Fiction: Risk and Reasonable Reliance in Estoppel’ (2014) Oxford Journal of Legal Studies (forthcoming).

${ }^{46}$ Woolcock Street Investments Pty Ltd v CDG Pty Ltd (2004) 216 CLR 515, 549 [80] (McHugh J).
} 
vulnerability subsumes the requirement of reasonable reliance. ${ }^{47}$ However, in most cases the concept appears to be another way of articulating the factors that inform reasonable reliance by the plaintiff. ${ }^{48}$ What is clear is that, however characterised, an objective fault-based standard of conduct informs this aspect of the enquiry.

In summary, the previous sections have considered how the combination of overlapping standards of reasonable foreseeability, actual or assumed knowledge, and reasonable reliance, operate to limit the scope of defendants' liability by restricting the circumstances in which they become subject to an actionable duty of care. Where these conditions are not met, liability will be precluded in toto. ${ }^{49}$ The defendant will owe no actionable duty so is liable for no loss. Where, on the other hand, a duty is both found and breached, the defendant is potentially liable for all the loss caused by her breach. Defendant liability is commonly further restricted at the remedial stage, through concepts also infused with standards of reasonable conduct, such as 'remoteness', ‘contributory negligence' and 'mitigation' requirements, to which we now turn.

\section{Remoteness and Reasonable Foreseeability of the Harm}

In the context of the law of negligence (including negligent misstatement ${ }^{50}$ ), the general test of remoteness is 'reasonable foreseeability'. This requirement plays an important, but not conclusive, role in negligent misstatement both in ascertaining the existence of a duty of care and in delimiting the defendant's scope of liability. ${ }^{51}$ It is useful to contrast this remoteness rule against those applied for intentional torts such as deceit. In the latter cases, the test of reasonable foreseeability is inapt: there is no reason to allow a fraudulent defendant to escape liability on the basis that a reasonable person would not have foreseen the loss. The fraudster is 'manifestly not a reasonable person'. ${ }^{52}$ Rather, the defendant will be liable for all damage consequent on and arising directly from the fraudulent misrepresentation. Thus, where the

\footnotetext{
${ }^{47}$ Perre v Apand Pty Ltd (1999) 198 CLR 180, 228 [124]-[125] (McHugh J).

${ }^{48} \mathrm{Cf}$ cases where it is dependence rather than reliance which is said to satisfy this required relationship of care between the parties: see Sutherland Shire Council v Heyman (1985) 157 CLR 424, 464 (Mason J).

${ }^{49}$ Esanda (1997) 188 CLR 241, 265 (Toohey and Gaudron JJ).

50 See, eg, Perre v Apand Pty Ltd (1999) 198 CLR 180, 248-9 [186] (Gummow J).

51 The dual role has made the separation of duty and remoteness considerations very difficult — and perhaps unhelpful: see, eg, Spartan Steel \& Alloys Ltd v Martin \& Co [1972] QB 27, 37 (Lord Denning MR). Cf Jolley v Sutton London Borough Council [2000] 3 All ER 409, 418 (Lord Hoffman).

52 In the context of injurious falsehood: Palmer Bruyn \& Parker v Parsons (2001) 208 CLR 388, 413 [78] (Gummow J). See also Doyle v Olby (Ironmongers) Ltd [1969] 2 QB 158, 167 (Lord Denning MR), cited in South Australia v Johnson (1982) 42 ALR 161, 170; and Gould v Vaggelas (1985) 157 CLR 215, 242 (Wilson J); cf 223-4 (Gibbs CJ).
} 
transaction in question involves purchase of an asset, the measure of liability will be the difference between the price paid and the 'real' or 'true' value of the asset (rather than its market value at the date of acquisition), taking into account all losses in value that are inherent to the asset up until the date of trial. ${ }^{53}$

The comparison demonstrates that remoteness rules in private law are closely tied to the nature of the claim. The remoteness rule must reflect and support the reason for the law's intervention in the particular category of case. ${ }^{54}$ The comparison also shows that the private law does not favour unrestricted liability, even in cases of flagrant wrongdoing such as deceit. Thus, while the approach to loss in the case of acquisition of an asset seems to expand the defendant's scope of liability considerably, taking into account intrinsic losses valued up until the date of trial, it also operates to exclude losses relating to the asset that are attributable to 'extraneous factors in the later history of the asset'. ${ }^{55}$ These extrinsic losses include losses caused by the gross negligence of the plaintiff in managing the asset. ${ }^{56}$ Objective carelessness on the part of the plaintiff also informs the final two restrictions on defendant liability, to which we now turn.

\section{E Contributory Negligence}

Contributory negligence originally operated as a very severe, bright line limitation on defendant liability: if the plaintiff was herself negligent contemporaneously or in association with the defendant's breach of a duty of care her claim failed in toto, however slight her comparative fault might have been. The harshness of this rule was mitigated by legislative reforms that allowed courts to apportion liability by reference to the respective fault of the parties. ${ }^{57}$

\footnotetext{
${ }^{53}$ Potts v Miller (1940) 64 CLR 282, 289-90 (Starke J), 297, 299 (Dixon J); Toteff v Antonas (1952) 87 CLR 647, 650-1 (Dixon J).

${ }^{54}$ In the statutory context, see Travel Compensation Fund v Tambree (2005) 224 CLR 627, 642-3 [45] (Gummow and Hayne JJ): 'the answer to the question of causation will require examination of the purpose of a particular cause of action, or the nature and scope of the defendant's obligation in the particular circumstances'.

${ }^{55}$ HTW Valuers Pty Ltd v Astonland Pty Ltd (2004) 217 CLR 640, 667 [65] (Gleeson CJ, McHugh, Gummow, Kirby and Heydon JJ).

${ }^{56}$ Gould v Vaggelas (1985) 157 CLR 215; I \& L Securities Pty Ltd v HTW Valuers (Brisbane) Pty Ltd (2002) 210 CLR 109 ('I \& L Securities').

${ }^{57}$ Civil Law (Wrongs Act) 2002 (ACT) s 102, Law Reform (Miscellaneous Provisions) Act 1965 (NSW) 9(1); Law Reform (Miscellaneous Provisions) Act (NT) s 16; Law Reform Act 1995 (Qld) s 10(1); Law Reform (Contributory Negligence and Apportionment of Liability) Act 2001 (SA) s 7; Wrongs Act 1954 (Tas) s 4; Wrongs Act 1958 (Vic) s 26(1); Law Reform (Contributory Negligence and Tortfeasors' Contribution) Act 1947 (WA) s 4(1).
} 
Contributory negligence operates as an important restriction on defendant scope of liability for negligent behaviour causing physical damage or harm. Its proper role in cases of negligent misstatement is somewhat less obvious. We have seen that plaintiffs in cases of contributory negligence must have demonstrated that their reliance was reasonable. It would seem that this leaves little room for the operation of contributory negligence as a limiting factor. ${ }^{58}$ Indeed, the operation of reasonable reliance as a factor that precludes defendant liability entirely is notably severe compared to the proportional operation of contributory negligence, which does not deny but reduces defendant liability. The judicial choice of a reasonable reliance requirement over the more generalised operation of contributory negligence is accordingly significant and must reflect the perceived strength of the policy concerns, discussed earlier, favouring restrictions on defendant liability. ${ }^{59}$

Contributory negligence is expressed and sometimes analysed in terms suggestive of factual causation: the plaintiff's award is reduced to the extent that she has contributed to her own loss. ${ }^{60}$ However, the purpose of the legislation is apportionment and courts have emphasised that the task is a comparison of relative culpability. ${ }^{61}$ Courts compare the degree to which each party has departed from the standard of the reasonable person. ${ }^{62}$ For this reason, it is clear that (as for the primary claim) normative and policy considerations play a strong role in contributory negligence: it is also for this reason that contributory negligence will usually play no role in the intentional torts. However, even in torts such as deceit, the plaintiff's failure to act reasonably may have a further role to play in limiting defendant liability. This is done through the closely related requirement of mitigation, to which we now turn.

\section{F $\quad$ Mitigation: taking reasonable steps to minimise loss}

The requirement that a plaintiff take reasonable steps following breach to mitigate her loss is common to all torts, including negligent misstatement and deceit. Although it is commonly called a 'duty to mitigate', a failure to mitigate does not give rise to an obligation to compensate

\footnotetext{
58 JEB Fasteners Ltd v Marks, Bloom \& Co [1981] 3 All ER 289. However it may be that in cases where reasonable reliance has been less crucial to a finding of breach of duty, for example, where reliance was intended, the limitation of contributory negligence may have more of a role to play.

59 P Cane, 'Negligence, Economic Interests and the Assessment of Damages' (1984) 10 Mon ULR 18, 39-40.

60 See above text at $\mathrm{n}$ XXX.

${ }^{61}$ Ibid; Podrebersek v Australian Iron \& Steel Pty Ltd (1985) 59 ALR 529, 532 (Gibbs CJ, Mason, Wilson, Brennan and Deane JJ).

62 Pennington v Norris (1956) 96 CLR 10, 16 (Dixon CJ, Webb, Fullagar and Kitto JJ); Podrebersek v Australian Iron \& Steel Pty Ltd (1985) 59 ALR 529, 532 (Gibbs CJ, Mason, Wilson, Brennan and Deane JJ). Also eg Wrongs Act 1958 (Vic) s 26(1).
} 
the defendant but rather results in a diminution of the plaintiff's damages to the amount that would have been awarded had the plaintiff acted prudently. ${ }^{63}$ It is closely associated with the date of assessment for loss (discussed previously in the context of deceit): losses that fall after the plaintiff should have taken steps to lessen or avoid her loss may be reduced or excluded. ${ }^{64}$ At base, the mitigation bar reflects the policy view that it is desirable for plaintiff losses to be stemmed as soon as reasonably possible and, conversely, that it is undesirable for a plaintiff to continue to amass losses in circumstances where she has the ability to minimise or avoid further damage. ${ }^{65}$ These policy considerations apply as much in cases of deceit as for negligent misstatement, although in the case of fraud the court will be relatively generous in determining what steps in mitigation a duped plaintiff can reasonably be expected to undertake. ${ }^{66}$

In summary, this brief review highlights the repeated use by courts of core conceptual criteria in the law of negligent misstatement. Courts draw on a number of standards of objective fault and related principles to analyse the relationship between the parties and their respective responsibility for the wrong alleged and any harm suffered as a result. These standards are also relevant in assessing defendant liability in cases of deceit, albeit to a lesser extent. This is important in the context of the statutory prohibition on misleading or deceptive conduct because, as we will see below, it is frequently alleged that liability for misleading and deceptive conduct is unaffected by objective standards of fault on the part of the defendant, ${ }^{67}$ such as intention or foresight on the part of the defendant and, other than under limited statutory provisions, the plaintiff's failure to take reasonable care of her own interests. If true, it suggests that the statutory prohibition constitutes a true and radical break from the common law doctrines applicable to misleading statements. However, as will become apparent, these protestations not only overstate the case: they tend to conceal the important role that common law concepts currently do and may yet play in limiting defendant liability under the statute.

\footnotetext{
63 Ardlethan Options Ltd v Easdown (1915) 20 CLR 285, 296-7 (Isaacs J). See also Munce v Vinidex Tubemakers Pty Ltd [1974] 2 NSWLR 235, 239 (Glass JA); Karacominakis v Big Country Developments Pty Ltd [2000] NSWCA 313 (17 November 2000) [187] (Giles JA, Hadley and Stein JJA agreeing); Arnott v Choy [2010] NSWCA 259 (6 October 2010) [155] (McColl JA, Basten JA agreeing).

${ }^{64}$ For the plaintiff to be required to have taken reasonable steps, the wrong must have occurred, and the plaintiff must know, or ought to know, the facts which give rise to the wrong: Ardlethan Options Ltd v Easdown (1915) 20 CLR 285, 296-7 (Isaacs J); Jones v Edwards (1994) 3 Tas R 350, 357 (Wright J); Mouritz v Hegedus [1999] WASCA 1061 (19 April 1999); Bak v Glenleigh Homes Pty Ltd [2006] NSWCA 10 (15 February 2006) [5], [8] (Handley JA), [62] (Hodgson JA).

65 Ardlethan Options Ltd v Easdown (1915) 20 CLR 285, 296 (Isaacs J).

${ }^{66}$ Doyle v Olby (Ironmongers) Ltd [1969] 2 QB 158, 167 (Lord Denning).

${ }^{67}$ Below at xxx.
} 
The analysis is also valuable in highlighting that the common law approaches to duty of care in negligent misstatement and deceit developed against a background of broader rules of contributory negligence, remoteness and mitigation. All components work together to articulate and delimit defendants' scope of liability, informed by the underlying policy reasons for the law's prohibition. This strongly suggests that it is neither possible nor desirable to draw on isolated components of these common law doctrines for the purposes of interpreting the statutory provisions by analogy without considering their role and fit in that broader context. Likewise, it is necessary to consider closely the role and fit of any common law analogy in the light of the words and purpose of the statute. It is to this nuanced process of enquiry that we now turn.

\section{LIMITING FACTORS UNDER THE ACL}

The prohibition on misleading or deceptive conduct in the ACL does not merely adopt and codify tort-based liability for misstatements. Rather, it creates a unique statutory cause of action. Although embedded in consumer protection legislation, it applies to all transactions 'in trade or commerce', regardless of the status of the plaintiff as consumer or trader. It can apply to protect members of the public and also commercial entities in their dealings with each other, although the approach taken to assessing whether conduct was misleading in these scenarios will differ. ${ }^{68}$ No intention to mislead or deceive is required to trigger statutory liability. A business 'which has acted honestly and reasonably may ... nevertheless be rendered liable'. ${ }^{6}$ The threshold question in assessing liability under $\mathrm{s} 18$ is whether the conduct was misleading or deceptive or likely to mislead or deceive. Liability at this stage is not dependent on proof of loss or damage to any person attributable to the proscribed conduct. ${ }^{70}$ If a plaintiff does seek compensation, courts must then assess what loss or damage has arisen 'because' of the defendant's conduct. ${ }^{71}$ In these, as in other respects, the statutory provisions differ markedly

\footnotetext{
${ }^{68}$ Miller \& Associates Insurance Broking v BMW Australia Finance (2010) 241 CLR 357 ('Miller v BMW Australia').

${ }^{69}$ Рuxu (1982) 149 CLR 191, 197 (Gibbs CJ).

${ }^{70}$ Discussed further immediately below at $\mathrm{xxx}$.

${ }^{71}$ ACL ss 236(1)(a), 237(1)(a), 238(1). On the predecessors of ss 236-8 (ss 82, 87 of the TPA) see Wardley Australia Ltd v Western Australia (1992) 175 CLR 514, 525 (Mason CJ, Dawson, Gaudron and McHugh JJ); Henville v Walker (2001) 206 CLR 459, 480 [61] (Gaudron J). This approach has been applied under the ACL: Maxton \& Maxton Australia Pty Ltd v Port Village Accommodation Pty Ltd [2012] FMCA 143 (21 February 2012) [45]-[53] (Lindsay FM); Norcast SARL v Bradken Ltd (No 2) (2013) 302 ALR 486, 566 [326] (Gordon J); Carter v Delgrave Holdings Pty Ltd [2013] FCCA 738 (12 July 2013) [145] (Lindsay J); Caffey v LeattHeyter (No 3) [2013] WASC 348 (18 October 2013) [326] (Beech J).
} 
from their common law counterparts that address negligent misstatements.

In that context, it is perhaps particularly apt that the High Court has repeatedly stated that it must be the words of the section that determine its application not analogy with the common law. ${ }^{72}$ Thus, in Murphy v Overton Investments Pty Ltd, the Court said:

This Court has now said more than once that it is wrong to approach the operation of those provisions of Pt VI of the Act which deal with remedies for contravention of the Act by beginning the inquiry with an attempt to draw some analogy with any particular form of claim under the general law. No doubt analogies may be helpful, but it would be wrong to argue from the content of the general law that has developed in connection, for example, with the tort of deceit, to a conclusion about the construction or application of provisions of Pt VI of the Act. To do so distracts attention from the primary task of construing the relevant provisions of the Act. $^{73}$

At same time it is difficult to start with an entirely clean slate. There is little direction provided in the legislation about how courts should proceed in making these assessments. The statute does not define key concepts such as the nature of the link between misleading or deceptive conduct and the loss suffered by the claimant or the meaning of 'loss or damage' for which damages or compensatory orders may be claimed. Recognising this, courts have also accepted that the common law provides 'an accumulation of valuable insight and experience which may well be useful in applying the Act'. ${ }^{74}$

Particularly where the statutory phrases echo well-known common law concepts, it is inevitable that courts will refer to the operation of those common law principles in interpreting the statute. Additionally, courts have accepted that a defendant's liability under the statute is limited. Given that the statutory norm spans both consumer and commercial dealings this not at all surprising. ${ }^{75}$ It follows that notwithstanding the unique and express policy purposes of the statute, similar types of considerations relating to responsibility for creating and managing risks

\footnotetext{
${ }^{72}$ Marks v GIO Australia Holdings Ltd (1998) 196 CLR 494, 503-4 [17] (Gaudron J), 510 [38] (McHugh, Hayne and Callinan JJ), 529 [103] (Gummow J), 549-50 [152] (Kirby J); Henville $v$ Walker (2001) 206 CLR 459, 470 [18] (Gleeson CJ), 501-2 [130]-[131] (McHugh J); I \& L Securities (2002) 210 CLR 109, 124-5 [42][48] (Gaudron, Gummow and Hayne JJ).

73 (2004) 216 CLR 388, 407 [44] (Gleeson CJ, McHugh, Gummow, Kirby, Hayne, Callinan and Heydon JJ) (citations omitted).

${ }^{74}$ Henville v Walker (2001) 206 CLR 459, 470 [18] (Gleeson CJ). See also Marks v GIO Australia Holdings Ltd (1998) 196 CLR 494, 512 [41] (McHugh, Hayne and Callinan JJ), 529 [102]-[103] (Gummow J), 542-3 [137][138] (Kirby J); Kenny \& Good Pty Ltd v MGICA (1992) Ltd (1999) 199 CLR 413, 460-1 [128]-[129] (Kirby and Callinan JJ).

${ }^{75}$ Puхи (1982) 149 CLR 191, 196-7 (Gibbs CJ); Miller v BMW Australia (2010) 241 CLR 357.
} 
that inform the interpretation of common law torts may remain relevant to the statutory prohibition. In particular, factors familiar from the law of torts, relating to the status of the defendant, the relationship between the defendant and the plaintiff and the plaintiff's response to the conduct in question naturally inform the enquiry into whether there has been a breach of the statutory prohibition. These types of factors again become relevant in assessing the extent to which the plaintiff has suffered loss or damage that should be compensated or remedied. On this analysis, the conceptual devices used by the common law have a useful role in guiding the courts' inquiry, not because of some blind transfer of common law concepts, but because they assist courts in identifying and organising the various considerations that may apply to assist the court in defining the scope of the defendant's statutory liability. The principles of the common law 'may provide guidance, for the reason that they have had to respond to problems of the same nature as the problems that arise in the application of the Act'. ${ }^{76}$

Courts applying s 18 have most commonly drawn upon cases dealing with deceit. Yet there may be much to be learned from the cases on negligent misstatement in framing questions of liability, both in characterising conduct as misleading and in defining the loss that must be compensated. ${ }^{77}$ As we have seen, the negligent misstatement cases engage with a complex range of considerations relevant in delineating the scope of liability of a defendant in its dealings with the plaintiff. Even where it is decided that tort concepts are not applicable to the legislation because, for example, they are inconsistent with its policy or purposes or the words of a particular section, this should better illuminate the nature of the statutory liability. The following sections accordingly consider, in the light of the approach taken in negligent misstatement, the comparative role played by objective fault-based standards in the statutory context as they relate to the conduct of defendants, plaintiffs and rules of remoteness, contributory fault and mitigation.

\section{A The Reasonable Defendant}

An immediate point of departure between negligent misstatement and the prohibition on misleading and deceptive conduct is that, subject to four caveats noted below, the fault of the defendant forms no part of the necessary conditions for breach of the statutory prohibition. ${ }^{78}$ The prohibition is concerned, rather, with the objective tendency of the defendant's conduct to

\footnotetext{
${ }^{76}$ Henville v Walker (2001) 206 CLR 459, 470 [18] (Gleeson CJ). See also Travel Compensation Fund v Tambree (2005) 224 CLR 627, 645 [45] (Kirby J).

${ }^{77}$ Henville v Walker (2001) 206 CLR 459, 470 [18] (Gleeson CJ).

${ }^{78}$ Рихи (1982) 149 CLR 191, 197-8 (Gibbs CJ).
} 
mislead or deceive. The defendant may engage in misleading or deceptive conduct innocently and with good justifications. The misleading conduct may be the outcome of honest and reasonable conduct. ${ }^{79}$ Indeed, it must be remembered that the prohibition can be contravened without anyone, in fact, have been misled by the conduct, as the High Court has recently emphasised. ${ }^{80}$ The statute aims to modify commercial behaviour by establishing certain norms of commercial practice, including that persons engaged in trade and commerce will not engage in misleading or deceptive conduct. ${ }^{81}$ Consistently, with this aim, the $A C L$ empowers regulators to monitor and bring actions in cases of potential contravention of the statutory norm simpliciter, that is without proof of loss or damage having been suffered by any person as a result of its breach. If the claim is sustained, the $A C L$ provides for the award of penalties for specific forms of misleading conduct ${ }^{82}$ and other enforcement powers designed to deter both the breaching party and others in like positions from engaging in misleading or deceptive conduct. Plaintiffs may also seek relief in respect of loss or damage suffered as a result of contravention of the statutory prohibition, but the ACL does not make caused loss a condition of defendant liability. ${ }^{83}$

Turning to limiting factors, typically, reasonable foreseeability of the plaintiff's reliance has no direct role to play at the point of identifying prohibited conduct under the ACL.${ }^{84}$ We have seen that the critical question at this point is whether the defendant's conduct was likely to mislead, not whether it did so and certainly not whether it actually caused harm to any identified person. Those latter-order questions generally only come into play at the point of remedies, particular at the stage of determining the defendant's liability for loss or damage suffered by a plaintiff by or because of the defendant's contravening behaviour. We return to the possible role of reasonable foreseeability in that context further below.

\footnotetext{
79 Ibid.

${ }^{80}$ Australian Competition and Consumer Commission v TPG Internet Pty Ltd (2013) 304 ALR 186, 196 [49], 198 [55] (French CJ, Crennan, Bell and Keane JJ), 202 [81] (Gageler J) ('ACCC v TPG Internet'). See also Рихи (1982) 149 CLR 191, 198 (Gibbs CJ).

${ }^{81}$ As the CCA s 3 states: it aims 'to enhance the welfare of Australians through the promotion of competition and fair trading and provision for consumer protection.'

${ }^{82}$ Se eg ACL ss 29 - 34.

${ }^{83}$ ACL s 237. See also Campbell v Backoffice Investments Pty Ltd (2009) 238 CLR 304, 318 [24] (French CJ); ACCC v TPG Internet (2013) 304 ALR 186, 196 [49], 197-8 [54] (French CJ, Crennan, Bell and Keane JJ).

${ }^{84}$ Butcher v Lachlan Elder Realty Pty Ltd (2004) 218 CLR 592, 605 [39] (Gleeson CJ, Hayne and Heydon JJ) ('Butcher').
} 
The statute is not concerned with the same dangers of indeterminacy that are used to justify the adoption of stringent duty rules in cases of negligent misstatement. The prohibition is against an identified category of conduct and, in theory at least, its contravention is entirely possible notwithstanding that no-one has been harmed by its breach. While the 'common understanding of commercial people' will be taken into account in determining whether particular conduct is misleading, ${ }^{85}$ the statutory prohibition of misleading or deceptive conduct cannot be undermined by conflicting, traditional common law conceptions of what constitutes acceptable commercial practices. Courts have recognised that the ACL gives effect to "“matters of high public policy", 86 and is to be "construed so as "to give the fullest relief which the fair meaning of its language will allow"' ${ }^{87}$ Finally, a point to which we will return below, the statutory prohibition does not require that a plaintiff must have acted reasonably to protect her own interests in order to obtain relief. That is, there is no statutory equivalent of the common law conception of 'vulnerability'.

The conclusion must be that the identified objective, defendant-oriented restrictions on imposing a duty of care recognised in the context of negligent misstatement are not directly analogous to determining the issue of prohibited behaviour under the statute. This does not, however, mean they entirely cease to be of relevance. In assessing whether there has been conduct contravening s 18, courts must consider the entirety of the circumstances and, in particular, the nature of the relationship between plaintiff and defendant (including a hypothetical plaintiff in cases where the claim is made by a regulator). It is only by examining the features of this relationship that courts can make an assessment of the actual or likely impact of the conduct and its effect on the plaintiff or putative plaintiff. In certain instances as part of this process the defendant's understanding of the plaintiff's likely reliance and the defendant's intention to mislead do become relevant to the characterisation of conduct as misleading under the ACL. Thus, any broad statement that the defendant's state of mind and the reasonableness of its conduct are not relevant to liability under s 18 is subject to at least four caveats.

\footnotetext{
${ }^{85}$ General Newspapers Pty Ltd v Telstra Corporation (1993) 45 FCR 164, 177-8 (Davies and Einfeld JJ). Also Poseidon Ltd v Adelaide Petroleum NL (1991) 105 ALR 25, 26 (Burchett J).

${ }^{86}$ Marks v GIO Australia Holdings Ltd (1998) 196 CLR 494, 528 [99] (Gummow J), citing ICI Australia Operations Pty Ltd v Trade Practices Commission (1992) 38 FCR 248, 256 (Lockhart J).

${ }^{87}$ Marks v GIO Australia Holdings Ltd (1998) 196 CLR 494, 528 [99] (Gummow J), citing Bull v AttorneyGeneral (NSW) (1913) 17 CLR 370, 384 (Isaacs J); Devenish v Jewel Food Stores Pty Ltd (1991) 172 CLR 32, 44 (Mason CJ); Webb Distributors (Australia) Pty Ltd v Victoria (1993) 179 CLR 15, 41 (McHugh J).
} 
The first caveat relates to the fact that what is prohibited is misleading conduct not the supply of inaccurate information. In order to assess whether conduct is misleading, or likely to mislead, courts have to consider the extent to which the defendant's conduct did or was likely to lead a person into error. This inquiry inevitably leads the court not merely to consider the perspective of the recipient but also the entirety of the conduct of the defendant, and the reasonableness of the steps it took to qualify its responsibility for any information it has imparted. ${ }^{88}$

The second caveat is that the defendant's state of mind may be relevant in assessing whether statements of opinion or statements as to the future are misleading. ${ }^{89}$ Moreover, as a result of s 4 , a representation with respect to a future matter will be taken to be misleading or deceptive unless the representor leads evidence that he or she had reasonable grounds for making the representation. ${ }^{90}$

The third caveat arises in assessing when silence is misleading. ${ }^{91}$ A defendant who fails to reveal critical information when it would be reasonable for the plaintiff to expect him to do so will have engaged in misleading conduct. ${ }^{92}$ This part of the inquiry would appear to focus on the plaintiff. Yet it is impossible to consider whether there is a reasonable expectation of disclosure on the part of the plaintiff without considering its relationship with the defendant. In addition some courts have interpreted the statute to require the defendant's silence to be deliberate before there can be liability for misleading and deceptive conduct. ${ }^{93}$ This possible

\footnotetext{
${ }^{88}$ See further the discussion of Butcher (2004) 218 CLR 592, below.

${ }^{89}$ See also the role of the defendant's grounds for a statement as to the future in establishing misleading conduct under the ACL s 4, discussed in Bennett v Elysium Noosa Pty Ltd (in Liq) (2012) 202 FCR 72, 124 [181] (Reeves $\mathrm{J}$ ); Jeannie Paterson, Andrew Robertson and Arlen Duke, Principles of Contract Law (Thomson Reuters, $4^{\text {th }}$ ed, 2012), 651-8; Arlen Duke, 'Representations as to the Future Under the Proposed Australian Consumer Law' (2009) 33 Melbourne University Law Review 454, 461-3. For contrasting views about the interpretation of the previous provisions (s 51A(2) TPA) and the onus of proof, see Ting v Blanche (1993) 118 ALR 543, 552; McGrath $\checkmark$ Australian Natural Products Pty Ltd (2008) 165 FCR 230, 242 [44] (Emmett J), 283 [192] (Allsop J).

${ }^{90}$ ACL s 4(2). For discussion, see Futuretronics v Gadzhis [1992] 2 VR 217, 240 (Ormiston J); North East Equity Pty Ltd v Proud Nominees Pty Ltd (2010) 269 ALR 262, 269 [33] (Sundberg, Siopis and Greenwood JJ); Paterson, Robertson and Duke, above n 89, 652.

${ }^{91}$ Estoppel is also a case in point: Lord Wilberforce in Moorgate Mercantile Co Ltd v Twitchings [1977] AC 890, 903 expressly adopts a test of reasonable reliance as to whether silence infringed a 'duty to speak':
}

the question [is] whether, having regard to the situation in which the relevant transaction occurred, as known to both parties, a reasonable man in the position of the 'acquirer' of the property, would expect the 'owner' acting honestly and responsibly, if he claimed any title in the property, to take steps to make that claim known to, and discoverable by, the 'acquirer' and whether, in the face of an omission to do so, the 'acquirer' could reasonably assume that no such title was claimed.

${ }^{92}$ See, eg, Henjo Investments Pty Ltd v Collins Marrickville Pty Ltd (1988) 39 FCR 546, 557 (Lockhart J).

${ }^{93}$ See, eg, Rhone-Poulenc Agrochimie SA v UIM Chemical Services Pty Ltd (1986) 12 FCR 477, 489 (Bowen CJ); Noor Al Houda Islamic College Pty Ltd v Bankstown Airport Ltd (2005) 215 ALR 625, 656-7 [187]-[190] 
limitation has been suggested to arise from the definition of conduct in the $A C L .{ }^{94} \mathrm{~A}$ requirement of deliberateness as an element of liability for misleading conduct will effectively operate as a requirement for the defendant to have knowledge of the plaintiff's reasonable expectation of disclosure. It is only in the face of this knowledge that the defendant's failure to disclose can be deliberate. Here we see something very similar to notions used in assessing common law negligent misstatement, of reasonable reliance and knowledge of reliance.

The fourth caveat relates to the role of defendant intention in determining whether conduct was 'likely to mislead or deceive'. We have seen that the defendant's intention to induce reliance plays an important role in deceit and has a somewhat similar role in negligent misstatement. ${ }^{95}$ In essence, the presence of intention allows courts to take a more generous approach to defendant liability. There are some signs that it has been used to cognate effect in relation to the statutory prohibition. ${ }^{96}$ Thus, although it stressed that deception was not required under the $A C L$, the High Court in ACCC $v$ TPG Internet noted that deliberate stratagems to induce reliance by focussing on some facts and omitting (or underplaying) others are more likely to be found to have induced reliance and hence be found to be misleading or deceptive. ${ }^{97}$ Intention is not a criterion of liability, but it is relevant to establishing breach of the statutory norm. That this distinction continues to have normative force under the $A C L$ is supported by the fact that the new apportionment provisions of s 138B of the CCA (which we consider further below) only apply to reduce a defendant's scope of liability where the defendant did not intentionally or fraudulently cause the damage.

In summary then, although the circumstances of the defendant, its state of mind, or its knowledge of the plaintiff's situation are not directly relevant to characterising conduct as misleading under the $A C L$, these notions or a variation of them do have a role in certain types

(Hoeben J). Cf CCP Australian Airships Ltd v Primus Telecommunications Pty Ltd (2005) ASAL \$55-139 [34] (Nettle JA).

${ }^{94}$ ACL 2(2). For this view under the previous provisions (s 4(2) TPA), see Rhone-Poulenc Agrochimie SA v UIM Chemical Services Pty Ltd (1986) 12 FCR 477, 489 (Bowen CJ). For further discussion, see Paterson, Robertson and Duke, above n 86, 649-51.

95 Above at $\mathrm{xxx}$ and $\mathrm{xxx}$.

96 Courts have also emphasised that inferences of reliance drawn in this manner may be rebutted by the circumstances of the transaction: Campbell v Backoffice Investments Pty Ltd (2009) 238 CLR 304, 351 [143] (Gummow, Hayne, Heydon and Kiefel JJ); De Bortoli Wines Pty Ltd v HIH Insurance Ltd (in liq) [2013] FCAFC 28 (15 March 2012) [67], [91]-[94] (Jacobson, Siopis and Nicholas JJ); Razdan v Westpac Banking Corporation [2014] NSWCA 126 (14 April 2014) [15]-[18] (McColl JA).

${ }^{97}$ ACCC v TPG Internet (2013) 304 ALR 186, 198 [55]-[57] (French CJ, Crennan, Bell and Keane JJ). 
of case. Here the courts' analysis might be made more transparent by recognising the common law parallels and indeed might benefit from the comparison.

\section{B The Reasonable Plaintiff}

When we turn to consider the position of the plaintiff, the picture changes considerably. An objective analysis of plaintiff behaviour is inherent in the statutory prohibition. This is because the statutory norm prohibits conduct that is 'misleading or deceptive, or likely to mislead or deceive'. Given the disjunctive phrase, which we have seen indicates that it is unnecessary to show that any person was actually misled or deceived, the statutory test necessarily requires a court to consider the objective impact of the impugned conduct, not its effect on the subjective state of mind of a particular plaintiff. ${ }^{98}$ In addressing this question, courts must consider what would be a reasonable response to the impugned conduct by the defendant. Where the object of the conduct is an identified individual, courts consider the response of a reasonable person with the characteristics of that individual. ${ }^{99}$ Where the conduct is directed towards a class of persons, or the public at large, courts consider what a 'representative member' of that class would make of the conduct and whether that representative person or member of a class would tend to act in reliance on the conduct. ${ }^{100}$ In both scenarios 'there must be a sufficient causal link between the conduct and error on the part of persons exposed to it'. ${ }^{101}$ In practice, this test functions as a weak requirement of reasonable reliance, excluding cases of unreasonable consumer reliance from the ambit of what constitutes proscribed conduct. While the protection of the legislation is not limited to the careful or the astute, ${ }^{102}$ even here reasonable care on the part of the recipient is expected. ${ }^{103}$ In the words of Gibbs CJ in Puxu:

It seems clear enough that consideration must be given to the class of consumers likely to be affected by the conduct. Although it is true, as has often been said, that ordinarily a class of consumers may include the inexperienced as well as the experienced, and the gullible as well as the astute, the section must in my opinion be regarded as contemplating the effect of the

\footnotetext{
${ }^{98}$ Рuхи (1982) 149 CLR 191, 198 (Gibbs CJ).

${ }^{99}$ Butcher (2004) 218 CLR 592, 604 [36]-[37] (Gleeson CJ, Hayne and Heydon JJ).

100 Campomar Sociedad Limitada v Nike International Limited (2000) 202 CLR 45, 85 [103] (the Court) ('Campomar'). See also Puxu (1982) 149 CLR 191, 199 (Gibbs CJ); Butcher (2004) 218 CLR 592, 604 [36] (Gleeson CJ, Hayne and Heydon JJ); Campbell v Backoffice Investments Pty Ltd (2009) 238 CLR 304, 319 [35] (French CJ).

${ }^{101}$ ACCC v TPG Internet (2013) 304 ALR 186, 194 [39] (French CJ, Crennan, Bell and Keane JJ). See also Butcher (2004) 218 CLR 592, [37].

${ }^{102}$ Henville v Walker (2001) 206 CLR 459, 468 [13] (Gleeson CJ).

${ }^{103}$ Campomar (2000) 202 CLR 45, 85 [102], citing Puxu (1982) 149 CLR 191, 199 (Gibbs CJ).
} 
conduct on reasonable members of the class. The heavy burdens which the section creates cannot have been intended to be imposed for the benefit of persons who fail to take reasonable care of their own interests. ${ }^{104}$

The similarity between excluding cases where the plaintiff failed to take reasonable care and the tort concept of reasonable reliance is even more apparent when courts are considering conduct directed at an individual. It is clear that High Court is alive to the context and that in assessing the standard of reasonable care, and indeed background knowledge, expected of recipients of information, both the forum of the statement and the intended audience are of crucial importance. For example, when that individual is in business, it is quite clear that the courts have certain expectations of self-responsibility, so that any reliance on the impugned statement of the defendant must be reasonable. A good example of the relevant mode of judicial reasoning is found in Butcher. ${ }^{105}$ The case involved a claim by a purchaser of property against a real estate agent. The purchaser argued that the agent had engaged in misleading conduct by including an inaccurate survey diagram in the brochure it produced to market the property. The brochure included the following disclaimer: 'All information contained herein is gathered from sources we believe to be reliable. However, we cannot guarantee it's [sic] accuracy and interested parties should rely on their own enquiries.' In the High Court the majority (Gleeson CJ, Hayne and Heydon JJ) held that the conduct was not misleading. ${ }^{106}$ In reaching this conclusion the majority held that it was necessary to consider the nature of the parties, the character of the transaction contemplated and what each party knew about the other as a result of the dealings, in order to determine what effect the conduct would have. ${ }^{107}$ The majority characterised the purchasers as 'intelligent, shrewd and self-reliant' business people who could be assumed to respond to the representation in question in a reasonable manner. ${ }^{108}$ The real estate agent was characterised as a business with a small staff that did not hold itself out as possessing the means of independently verifying title details of property. ${ }^{109}$ Given the nature of the parties, the nature of the transaction and the presence of the disclaimer, the majority concluded that the conduct was not misleading or deceptive — the disclaimer made it clear that

\footnotetext{
104 (1982) 149 CLR 191, 199 (Gibbs CJ). See also Miller v BMW Australia (2010) 241 CLR 357, 371 [22] (French CJ and Kiefel J).

105 (2004) 218 CLR 592. See also Miller v BMW Australia (2010) 241 CLR 357.

${ }^{106}$ Butcher (2004) 218 CLR 592, 605 [40] (Gleeson CJ, Hayne and Heydon JJ).

${ }^{107}$ Ibid 604-5 [37].

108 Ibid 606 [41].

${ }^{109}$ Ibid 606 [42].
} 
the real estate agent was not representing that the diagram in question was accurate. ${ }^{110}$

This sensitivity to context on the part of the court can produce very different results where the circumstances change only slightly. ACCC $v$ TPG Internet $^{111}$ involved a multimedia advertisement campaign conducted by TPG using TV, radio, newspapers and websites. In its headline offer, it offered 'Unlimited ADSL2+', an internet broadband service, to consumers for \$29.99 per month. In fact the offer was qualified: ADSL2+ was available only when bundled with TPG's home phone service for an additional \$30 per month (with a minimum 6month commitment) and consumers were required to pay an additional setup fee plus a deposit for telephone charges. These charges were disclosed in fine print under the headline offer.

The Federal Court accepted the submissions of the Australian Competition and Consumer Commission ('ACCC') that the advertisements were misleading or deceptive due to the disparity between the prominent headline offer of $\$ 29.99$ and the actual offer terms. This finding was set aside on appeal in the Full Court of the Federal Court but reinstated in the High Court. The High Court accepted the reasoning of the trial judge to the effect that the advertisements had a dominant message, namely: 'Unlimited ADSL2+ for \$29.99 per month'. This would for the ordinary consumer create an impression that the entire cost of the service was \$29.99 per month. Qualifications to this cost were not given sufficient prominence to counter the effect of the headline claim. ${ }^{112}$ The failure of consumers to pay attention to the qualifying words could not be equated with a lack of care on their behalf. The High Court explained that:

the advertisements were an unbidden intrusion on the consciousness of the target audience. The intrusion will not always be welcome. The very function of the advertisements was to arrest the attention of the target audience. But while the attention of the audience might have been arrested, it cannot have been expected to pay close attention to the advertisement ... That being so, the attention given to the advertisement by an ordinary and reasonable person may well be 'perfunctory', without being equated with a failure on the part of the members of the target audience to take reasonable care of their own interests. ${ }^{113}$

It was not sufficient to contend that many consumers may know that ADSL2+ services are often offered as part of a 'bundle'. This knowledge would not 'defuse' the advertisements'

\footnotetext{
${ }^{110}$ Ibid 605 [40], 609 [51], 615-16 [75].

111 (2013) 304 ALR 186.

${ }^{112}$ ACCC v TPG Internet (2013) 304 ALR 186, 198 [57] (French CJ, Crennan, Bell and Keane JJ).

113 Ibid 196 [47].
} 
tendency to mislead in circumstances where the target audience was left with only the 'dominant message' at the end of the advertisement. ${ }^{114}$ Rather, consumers were likely to be misled by TPG's advertisements because the advertisements had selected some words for emphasis and failed to neutralise the effect of this: instead, it 'relegated the balance to relative obscurity'. ${ }^{115}$ In this regard, the High Court affirmed the proposition that 'where a representation is made in terms apt to create a particular mental impression in the representee, and is intended to do so, it may properly be inferred that it has had that effect.' ${ }^{116}$

\section{Remoteness and Foreseeability of Harm}

The limiting role of objective standards of fault has arguably also emerged in assessing the remedy available to plaintiffs who have established misleading conduct and are seeking a response to loss suffered by them. Courts have repeatedly stressed that the language of the Act does not admit of restrictions on liability arising from carelessness or fault on the part of the plaintiff that is not itself wrongful under the ACL. ${ }^{117}$ Thus, in I \& L Securities, Gaudron, Gummow and Hayne JJ stated:

it would ... be anomalous if s 87 were to be read in such a way as would permit the claimant's carelessness (not in contravention of the Act) to be taken into account to reduce the amount of the loss or damage caused by the contravener's conduct... ${ }^{118}$

So too it has been said that:

There is nothing in s 82, in other provisions of the Act or in the policy of the Act to suggest that a plaintiff's right to relief for loss of which the contravening conduct was a cause depends in any way on him or her having taken reasonable care for his or her own interests. ${ }^{119}$

But such blanket assertions must be qualified to the extent that they would deny the roles we have previously seen played by the concept of reasonable care or its absence, or, more generally, reasonable reliance in determining contravention of s 18. These statements arguably also overstate the case in denying any role under the statute to common law concepts such as

\footnotetext{
${ }^{114}$ Ibid 197 [53].

115 Ibid 197 [51].

116 Ibid 198 [55].

117 See, eg, Henville v Walker (2001) 206 CLR 459, 468 [13] (Gleeson CJ).

118 (2002) 210 CLR 109, 129 [60] (emphasis in original).

${ }^{119}$ Havyn Pty Ltd v Webster [2005] NSWCA 182 (26 May 2005) [116], citing Henville v Walker (2001) 206 CLR 459, 468 [13] (Gleeson CJ): 'The purpose of the legislation is not restricted to the protection of the careful or the astute’. See also I \& L Securities (2002) 210 CLR 109, 121-2 [33] (Gleeson CJ), 126-130 [50]-[62] (Gaudron, Gummow and Hayne JJ), 138 [91]-[92] (McHugh J), 178 [217] (Callinan J).
} 
remoteness, contributory negligence and mitigation, in which considerations of the reasonableness of the plaintiff's behaviour commonly play a leading part. As we will see, in this context there has been a shift from the paradigm of apparently strict liability under the statute to one where lessons drawn from negligent misstatement are increasingly apposite.

The statutory remedies provided under the $A C L$ are available where a person has suffered loss 'because of' conduct prohibited by the $A C L,{ }^{120}$ and 'by' the conduct under the predecessor legislation the TPA. ${ }^{121}$ These words have been understood as expressing a requirement of causation. ${ }^{122}$ It is notable that there is no language of remoteness employed on the face of the relevant provisions. In the light of that omission, and consistently with the protective aims of the statute, it would be entirely rational (if rather harsh) for the statute to take the position that, in order to promote high standards of conduct by repeat traders, and to protect gullible and irrational consumers, that the plaintiff should be entitled to all loss caused as a matter of fact by the defendant's misleading or deceptive conduct. ${ }^{123}$

Consistently with that position, courts have recognised that there is nothing in the words of the statutory prohibition and associated remedies to suggest that a defendant's liability is subject to the remoteness considerations that might apply under cognate general law areas. ${ }^{124}$ Gleeson CJ in Henville $v$ Walker noted that the 'only express guidance' under the Act with respect to assessment of damages is the concept of causation expressed by the word 'by' (or now 'because of'). ${ }^{125}$ 'The task is to select a measure of damages which conforms to the remedial purpose of the statute and to the justice and equity of the case. ${ }^{126}$ However, this recognition has not led to wholesale rejection of the applicability of remoteness considerations under the statute. This is because courts have also taken the view that the language of causation employed by the $A C L$ does not relate solely to the purely factual question of whether the defendant's breach of the statutory norm as a matter of history led to the loss that in fact occurred. It additionally encompasses the quite separate question of whether a defendant should be held responsible for

\footnotetext{
${ }^{120}$ ACL ss 236(1)(a), 237(1)(a).

121 TPA ss 82, 87.

122 See, eg, Wardley Australia Ltd v Western Australia (1992) 175 CLR 514, 525 (Mason CJ, Dawson, Gaudron and McHugh JJ); Henville v Walker (2001) 206 CLR 459, 489 [95] (McHugh J).

123 See, eg, Henville v Walker (2001) 206 CLR 459, 506 [144] (McHugh J).

${ }^{124}$ Marks v GIO Australia Holdings Ltd (1998) 196 CLR 494, 509 [34] (McHugh, Hayne and Callinan JJ).

125 (2001) 206 CLR 459, 470 [18] (Gleeson CJ).

${ }^{126}$ Henville v Walker (2001) 206 CLR 459, 470 [18] (Gleeson CJ).
} 
that outcome, a matter that raises normative questions and concerns regarding the appropriate limitations on defendants' scope of liability under the legislation. ${ }^{127}$

The language of 'common law practical or common-sense' causation has commonly been deployed by Australian courts to aggregate these enquiries into both the factual and normative conditions for liability. ${ }^{128}$ This can lead to serious confusion about the conditions for and limits on defendant liability. ${ }^{129}$ In particular, in the context of the prohibition on misleading or deceptive conduct, courts have frequently been concerned that to apply the usual 'a factor' 130 test of factual causation will leave defendants in the position of insurers of plaintiff losses. ${ }^{131}$ To the extent that the language of 'causation' is being used to cover two quite separate issues (factual causation and normative or policy-based conditions for legal responsibility), there is a danger of losing sight of the fact that factual causation is but one part of a much greater liability enquiry.

One positive outcome of the widespread use of the language of 'legal' or 'common-sense' causation in the case law on misleading conduct is that it enables courts to take a similarly broad approach to the language of causation used under the Act. ${ }^{132}$ Insofar as courts recognise that 'common sense' causation is an inquiry into scope of liability, they have opened the door to consideration of limiting concepts such as remoteness. In the words of Gleeson CJ in $I \& L$ Securities:

The misrepresentation will rarely be the sole cause of the loss. In statements of principle concerning the common law of contract or tort, additional factors which affect loss or damage are often discussed under the rubrics of remoteness, mitigation, or contributory negligence.

\footnotetext{
${ }^{127}$ Ibid 489-91 [96]-[98], 504 [136] (McHugh J, with whom Gummow J agreed); I \& L Securities (2002) 210 CLR 109, 119 [26] (Gleeson J), cited in Allianz Australia Insurance Ltd v GSF Australia Pty Ltd (2005) 221 CLR 568, 598 [100]; (2005) 224 CLR 627, 639 [30] (Gleeson CJ), 643 [46]-[47] (Gummow and Hayne JJ), 654 [81] (Callinan J).

${ }^{128}$ Wardley Australia Ltd v Western Australia (1992) 175 CLR 514, 525 (Mason CJ, Dawson, Gaudron and McHugh JJ); Henville v Walker (2001) 206 CLR 459, 489 [95], 493 [105], 504 [138] (McHugh J).

${ }^{129}$ The two stage inquiry required under Australian Civil Liability Acts addresses this concern by requiring courts to consider both factual causation and scope of liability questions when assessing causation: Civil Law (Wrongs) Act 2002 (ACT) s 45(1); Civil Liability Act 2002 (NSW), s 5D(1); Civil Liability Act 2003 (Qld) s 11(1); Civil Liability Act 1936 (SA) s 34(1); Civil Liability Act 2002 (Tas) s 13(1); Wrongs Act 1958 (Vic) s 51(1); Civil Liability Act 2002 (WA) s 5C(1).

${ }^{130}$ I \& L Securities (2002) 210 CLR 109, 122 [31]-[33] (Gleeson CJ); 128 [57] (Gaudron, Gummow and Hayne $\mathrm{JJ})$.

${ }^{131}$ Hay Property Consultants Pty Ltd v Victorian Securities Corporation Limited [2010] VSCA 247 (22 September 2010) [86]-[90] (Neave JA) ('Hay Property').

${ }^{132}$ Here indeed we may see the influence of Civil Liability legislation in refining the courts' approach to causation under the ACL so as explicitly to deal with both aspects of the causation puzzle.
} 
Here we are concerned, not with common law principles, but with statutory rights and liabilities. However, the same problems arise, and must be dealt with in conformity with the statute.

The relationship between conduct of a person that is in contravention of the statute, and loss or damage suffered, expressed in the word 'by', is one of legal responsibility. Such responsibility is vindicated by an award of damages. When a court assesses an amount of loss or damage for the purpose of making an order under s 82, it is not merely engaged in the factual, or historical, exercise of explaining, and calculating the financial consequences of, a sequence of events, of which the contravention forms part. It is attributing legal responsibility; blame. This is not done in a conceptual vacuum. It is done in order to give effect to a statute with a discernible purpose; and that purpose provides a guide as to the requirements of justice and equity in the case. Those requirements are not determined by a visceral response on the part of the judge assessing damages, but by the judge's concept of principle and of the statutory purpose. ${ }^{133}$

What remoteness rules have been identified as applicable under the Act? As Gleeson CJ makes clear, the rules limiting liability under the statute must (as at common law) be informed by the purpose of the law's prohibition. ${ }^{134}$ The statute clearly aims strongly to deter certain forms of commercial conduct and in so doing, promote fair trading and consumer protection. ${ }^{135}$ This combination of aims and the direct prohibition on deceitful conduct makes deceit an apt source of analogical reasoning. We saw previously that in deceit, the law seeks to draw boundaries between 'direct' and 'indirect' losses, or losses intrinsic and external to assets acquired in reliance on the defendant's misrepresentation. ${ }^{136}$ It also recognises a mitigation requirement, itself closely linked to the concept of direct and indirect losses. Thus where a business purchased as a result of the defendant's fraud has suffered losses as a result of the gross negligence of the plaintiff in continuing trading after she should have ceased, a line may be drawn under those losses which must be borne by the plaintiff. ${ }^{137}$ Whether viewed as 'external' losses or a failure to mitigate, the defendant is not held responsible for those losses, notwithstanding they were undoubtedly caused as a matter of historical fact by her breach.

\footnotetext{
133 I \& L Securities (2002) 210 CLR 109, 119 [25]-[26] (Gleeson CJ).

134 Ibid 119 [26], 121 [33] (Gleeson CJ). See also Allianz Australia Insurance Ltd v GSF Australia Pty Ltd (2005) 221 CLR 568, 597 [99] (Gummow, Hayne and Heydon JJ); Travel Compensation Fund v Tambree (2005) 224 CLR 627, 643-4 [49] (Gummow and Hayne JJ); Henville v Walker (2001) 206 CLR 459, 489 [96] (McHugh J).

${ }^{135}$ CCA s 2; Henville v Walker (2001) 206 CLR 459, 489 [96], 503 [135] (McHugh J).

136 See above xxx.

${ }^{137}$ See above $\mathrm{xxx}$.
} 
Much the same sorts of limiting factors have been identified as being relevant to limiting defendant liability under the statute for misleading and deceptive conduct. In HTW Valuers $v$ Astonlond $^{138}$ ('HTW Valuers') the plaintiff was considering purchasing a small shopping arcade, near which a new shopping centre was being constructed. The plaintiff sought advice from the defendant about retail rental levels in the area. On the basis of that advice the plaintiff entered into a contract to purchase the shopping arcade. The net rent collected from the property fell dramatically over the next three year period. The trial judge found that the defendants had engaged in misleading conduct contrary to the legislation by failing to qualify its advice by reference to the uncertain effect of the imminent opening of the new shopping centre. The High Court affirmed that the correct award of damages should be reached by deducting the 'true' value of the arcade at the date of acquisition from the purchase price. The losses to the plaintiff brought about by the fact that a rival shopping centre opened after the purchase date, were deemed to be losses intrinsic to the asset originally purchased, and therefore recoverable. The court distinguished this from situations where aspects of the total loss are brought about by events which are 'independent, extrinsic, supervening or accidental' 139 — for example by 'unexpected competition'. ${ }^{140}$ In HTW Valuers, the subsequent events which exacerbated the plaintiff's loss arose from 'expected competition' ${ }^{141}$ and "“the nature” of the Plaza and its commercial and geographical environment; they were not events which arose from "sources supervening upon or extraneous to the fraudulent inducement”". ${ }^{142}$ In I \& L Securities, Gleeson CJ gave as instances where defendant liability might properly be reduced:

a case in which there had been grossly unreasonable conduct on the part of a lender in realising a security; conduct that in a common law context may be regarded as a supervening cause of part of the ultimate loss. ... [an] act of a third party, or the influence of [an] external event or circumstance ... that contributed to the financial outcome of the loan transaction. ${ }^{143}$

\footnotetext{
138 (2004) 217 CLR 640.

${ }^{139}$ HTW Valuers (2004) 217 CLR 640, 659 [40] (Gleeson CJ, McHugh, Gummow, Kirby and Heydon JJ), quoting Potts v Miller (1940) 64 CLR 282, 298 (Dixon J).

${ }^{140}$ HTW Valuers (2004) 217 CLR 640, 660 [42].

141 Ibid.

${ }^{142}$ HTW Valuers (2004) 217 CLR 640, 660 [43] (Gleeson CJ, McHugh, Gummow, Kirby and Heydon JJ).

143 (2002) 210 CLR 109, 119-120 [27] (Gleeson CJ).
} 
On this analysis, the purpose of the statute supports the view that the objective failure of a plaintiff to take care to protect her own interests may be relevant here, just as it was when characterising conduct as misleading or deceptive. ${ }^{144}$

However, prior to the introduction of apportionment provisions to the statute, the circumstances in which a reasonableness requirement could operate to diminish defendant liability were restricted. This is because in $I$ \& $L$ Securities the High Court held that there was nothing in the Act to permit apportionment of liability in cases where the damage was an 'indivisible' consequence of the defendant's breach. ${ }^{145}$ In that case, the plaintiff financier relied on the defendant's misleading valuation of property in making a loan, however failed to take reasonable steps to assess independently the borrower's capacity to repay. The defendant's plea that the plaintiff's concurrent role in bringing about its own loss should operate in diminution of the defendant's total liability failed. ${ }^{146}$ The Court noted that in some comparatively rare instances (such as those suggested by Gleeson $\mathrm{J}$ ) it would be possible and appropriate to divide up the loss suffered and attribute part to severable acts of the plaintiff or third parties. ${ }^{147}$ But a person who contravened the Act was otherwise liable for all of the indivisible loss of another that was attributable to the contravention. The Court could not apportion indivisible loss or damage suffered by the plaintiff in accordance with the parties’ culpability. ${ }^{148}$

By contrast, a good example of a case where loss was divisible was Hay Property. ${ }^{149}$ In that case, as in I \& L Securities, the defendant provided a negligent valuation on which a financier relied in making a loan. When the borrower defaulted, the lender suffered a loss. However, in Hay Property, the loss was exacerbated by acts of vandalism to the property by unknown third parties, which severely diminished the value of the property before sale. Neave JA (with whom the other justices agreed) considered that the Act did not aim to make persons in the position of the defendant the insurer of all loss that flowed from breach of the statutory prohibition. ${ }^{150}$ Nor did the purpose and policy of the TPA require that a negligent valuer be held liable for loss

\footnotetext{
${ }^{144}$ Henville v Walker (2001) 206 CLR 459, 474 [36].

145 (2002) 210 CLR 109, 117-18 [20] (Gleeson CJ), 128 [57] (Gaudron, Gummow and Hayne JJ), 138 [92], 141 [102] (McHugh J).

${ }^{146}$ See also Henville v Walker (2001) 206 CLR 459, 505 [140] (McHugh J), 510 [166]-[167] (Hayne J).

${ }^{147}$ I \& L Securities (2002) 210 CLR 109, 119-120 [27] (Gleeson CJ).

148 I \& L Securities (2002) 210 CLR 109, 117 [20], 121-2 [33] (Gleeson CJ), 126 [50] (Gaudron, Gummow \& Hayne JJ), 137-8 [89]-[93], 141 [102] (McHugh J), 177-8 [216]-[217] (Callinan J).

149 [2010] VSCA 247 (22 September 2010).

150 Ibid [90].
} 
caused by the criminal acts of third parties unrelated to the contravening conduct, unrelated in the sense that it did not increase the risk of the sort of loss that in fact occurred. ${ }^{151}$ The criminal acts of the third parties in her Honour's view ‘[broke] the chain of causation' and gave rise to a distinct and severable amount of loss that should be excluded from the award. ${ }^{152}$ Notably, in coming to this conclusion, Neave JA expressly drew on the analogous position taken under the law of negligence. ${ }^{153}$

In summary, courts have repeatedly recognised that remoteness rules may apply under the Act consistently with its purpose, including considerations based on the reasonable conduct of the defendant. Unfortunately, this reasoning is often obscured by the unhelpful merging of the cause-in-fact enquiry with the separate question of relevant normative and policy considerations that work to restrict liability. Language such as 'legal' or 'common-sense' causation, intervening acts that 'break the chain of causation' and so on tend to suggest that there is some scientific principle at work, determining which fact or matter amongst others are relevant causes of the loss that has occurred. In truth, however, here as at common law the remoteness principles are deeply informed by the reasons for the law's prohibition of the defendant's behaviour. These reasons are primarily founded in the policy of the Act and value judgments about the proper scope of defendant liability in the light of that legislative purpose. ${ }^{154}$ None of it is straightforward and all requires an exercise of active judgment.

Other High Court cases have also emphasised the importance of identifying the purpose of applicable legislation (other than and in addition to the $A C L$ ) to place proper limits on defendant liability. A good example is Travel Compensation Fund $v$ Tambree. ${ }^{155}$ The defendants had provided misleading reports of the financial position of a third party travel agency to the plaintiff, Travel Compensation Fund. In reliance on these reports, the Fund had allowed the third party to continue to participate in the Fund, which was a condition of holding a travel agency licence. At the subsequent request of the agency's director, the Travel Compensation Fund terminated her business' participation in the Fund, with the result that she lost the agency licence and should have ceased trading. However, she unlawfully continued in business,

\footnotetext{
${ }^{151}$ Ibid [89].

${ }^{152}$ Ibid [86], [91].

153 Ibid [92].

154 Travel Compensation Fund v Tambree (2005) 224 CLR 627, 643 [45] (Gummow and Hayne JJ) xxx (Kirby $\mathrm{J})$.
} 
amassing further liabilities to customers for which the Fund became liable. The defendants argued that they could not be held liable for those additional losses suffered: the continued unlawful trading of the third party business constituted, it was claimed, a 'break' in the chain of causation.

The High Court disagreed, noting that the sort of unlawful activity was the very kind of risk against which the Travel Compensation Fund had sought assurance when it requested and received account and audit advice. Critical in determining that the loss was not too remote was the purpose of the statutory regime pursuant to which the Fund was established. In the words of Gleeson CJ:

The whole purpose of the scheme is to protect the public against loss resulting from dealing with defaulting agents. Default commonly results from financial failure, and failure to account by an agent may well involve some form of illegality. When the appellant called for audited financial statements, the kind of loss to the public, and the kind of loss to itself, against which it sought protection was loss that would always involve an agent's failure to account. ${ }^{156}$

Gleeson CJ, with whom Gummow, Hayne and Callinan JJ agreed, concluded that the unlawful conduct of the travel agent did not fall outside the 'scope of risk' against which the Fund had sought to protect itself. ${ }^{157}$

In this respect, it is interesting that the reasoning of Gummow and Hayne $\mathrm{JJ}$ in that case emphasised that, subsequent to the contravening conduct, the plaintiff had acted reasonably in terminating the failing business' participation in the scheme, as had the Department of Fair Trading in shutting down the business once the fact of continued unlawful trading surfaced. ${ }^{158}$ Neither of these events therefore 'broke' the chain of causation. However, we have seen that the conclusion that some act or event 'broke' or did not break the chain of causation is a normative or policy-based one, not a conclusion of historical fact. ${ }^{159}$ In all these cases, it is undeniable that, as a matter of historical fact, the defendant's breach was a factual cause of all the loss that occurred. In that context, the conclusion that the chain of causation has or has not been broken rests on normative concepts of reasonableness familiar from the remoteness (and

\footnotetext{
156 Travel Compensation Fund v Tambree (2005) 224 CLR 627, 638-9 [27].

157 Ibid 638-9 [27], 640 [34] (Gleeson CJ). See also at 641 [40]-[41] (Gummow and Hayne JJ), 652 [73]-[74] (Kirby J).

158 Ibid 642 [43].

159 See above. Also Kirby J in I \& L Securities (2002) 210 CLR 109, 153-4 [144].
} 
mitigation ${ }^{160}$ ) rules relating to deceit and negligent misstatement. These normative concepts are quite independent of the question of factual causation and are not explicit on the face of the statute. Their Honours' emphasis on the reasonableness of the plaintiff's conduct confirms the normative nature of the inquiry.

What other support is there in the authorities for the operation of conceptions of remoteness under the ACL? In Henville $v$ Walker, McHugh $\mathrm{J}$ suggested that causation under the Act incorporated the concept of remoteness, excluding responsibility for loss or damage that 'was not reasonably foreseeable even in a general way by the contravener.' ${ }^{161}$ The incorporation of a reasonable foreseeability test would constitute a clear departure from the stricter test of 'direct loss' applicable in cases of deceit and suggests a direct analogy with negligent misstatement. ${ }^{162}$ This might seem to tell against the appropriateness of the criterion in the context of the statute. But it will be recalled that the criterion of reasonable foreseeability was rejected for deceit because the defendants in such cases are by definition unreasonable. ${ }^{163}$ The same cannot be said for all defendants in cases of misleading and deceptive conduct. Nor is fraud a condition of defendant liability under the Act. So it would not seem to be incoherent to limit liability for loss in cases where the defendant contravened the statute innocently or on reasonable grounds and in circumstances where the plaintiff's loss or damage was not reasonably foreseeable. Notably, on this approach, reasonable foreseeability would remain irrelevant to the process of characterising conduct as misleading or deceptive. It would only come into play at the stage of determining the scope of the defendant's liability for loss.

This conclusion depends on it being possible and proper to disaggregate the conditions of contravention of s 18 from the considerations bearing on defendant liability for loss caused by that breach. It is arguable that it is for two main reasons. The first is because the prohibition of misleading or deceptive conduct is actionable without loss. It follows that the informing considerations for determining liability under that provision may differ from those that inform liability for loss. The second and related point is that liability for loss is contingent on proof that the loss was caused 'by' or 'because of' the defendant's breach and, as we have seen, this

\footnotetext{
160 See further below at $\mathrm{xxx}$.

${ }^{161}$ Henville v Walker (2001) 206 CLR 459, 504 [136] (McHugh J, with whom Gummow J agreed). McHugh J also stressed, however, that on his view remoteness does not incorporate situations where the plaintiff has not acted reasonably: at 504 [136], a point which works to ensure that relief under the statute is not limited to reasonable plaintiffs.

162 Ibid 503-4 [135]-[136] (McHugh J).

163 Above at xxx.
} 
language denotes not merely factual causation, but the normative and policy-based conditions that inform the defendant's scope of liability. Notwithstanding these considerations, the point remains a difficult one that also arises in respect of the apportionment provisions, to which we now turn.

\section{Apportioning Fault and Contributory Negligence}

We have seen that, prior to the enactment of apportionment provisions under the TPA and subsequently the CCA, Australian courts had fairly consistently set their face against taking the plaintiff's carelessness in connection or contemporaneously with the defendant's breach into account when determining the defendant's level of liability for loss. The relevance of the plaintiff's care for his or her own interests has been said to be relevant to the scope of liability only in exceptional cases. ${ }^{164}$ This was said to be because such loss was 'indivisible' and the TPA made no provision for apportionment. ${ }^{165}$ Less convincingly, it was further said to be 'anomalous' that the claimant's carelessness (not in contravention of the Act) should be taken into account to reduce the amount of the loss or damage caused by the contravener's conduct, ${ }^{166}$ although we have also seen that the reasonableness of the plaintiff's behaviour has informed that question in other contexts. ${ }^{167}$ Thus in Henville $v$ Walker, a majority would have held that the defendant was liable for all of the losses caused by his contravention of the statute, notwithstanding the plaintiff's own carelessness in preparing a seriously inaccurate feasibility study on which he also relied. ${ }^{168}$ A similar result was reached in I \& L Securities where the plaintiff's failure independently to check the creditworthiness of a borrower was not taken into account to reduce the defendant's liability for loss arising from its misleading property valuation. ${ }^{169}$

\footnotetext{
${ }^{164}$ Argy v Blunts and Lane Cove Real Estate Pty Ltd (1990) 26 FCR 112, 138; Henville v Walker (2001) 206 CLR 459, 468 [13] (Gleeson CJ), 493 [106] (McHugh J); I \& L Securities (2002) 210 CLR 109, 136 [85] (McHugh J), 154 [144] (Kirby J, citing French J in Pavich v Bobra Nominees Pty Ltd (1988) ASC 55-684).

165 See, eg, I \& L Securities (2002) 210 CLR 109, 141 [102], 144 [112] (McHugh J).

${ }^{166}$ Ibid 129 [60] (Gaudron, Gummow and Hayne JJ).

167 See, eg, I \& L Securities (2002) 210 CLR 109, 120 [28]-[29] (Gleeson CJ), 137 [88]-[89] (McHugh J), citing Tefbao Pty Ltd $v$ Stannic Securities Pty Ltd (1993) 118 ALR 565, 575 (Hodgson J).

168 (2001) 206 CLR 459, 469 [14] (Gleeson CJ), 482 [66] (Gaudron J), 501 [129] (McHugh J), 509 [163] (Hayne $\mathrm{J})$.

169 (2002) 210 CLR 109, 117 [20], 121-2 [33] (Gleeson CJ), 126 [50] (Gaudron, Gummow \& Hayne JJ), 137-8 [89]-[93], 141 [102] (McHugh J), 177-8 [216]-[217] (Callinan J).
} 
This picture has now changed with the introduction of apportionment provisions under s 137B of the $C C A .{ }^{170}$ Section $137 \mathrm{~B}$ (based on its predecessor s $82(1 \mathrm{~B})$ of the TPA) relevantly states:

If:

(a) a person (the claimant) makes a claim under subsection 236(1) of the Australian Consumer Law in relation to economic loss, or damage to property, suffered by the claimant because of the conduct of another person; and

(b) the conduct contravened section 18 of the Australian Consumer Law; and

(c) the claimant suffered the loss or damage as a result:

(i) partly of the claimant's failure to take reasonable care; and

(ii) partly of the conduct of the other person; and

(d) the other person did not intend to cause the loss or damage and did not fraudulently cause the loss or damage;

the amount of the loss or damage that the claimant may recover under subsection 236(1) of the Australian Consumer Law is to be reduced to the extent to which a court thinks just and equitable having regard to the claimant's share in the responsibility for the loss or damage.

As yet, there has been no extended analysis of the operation of this section. ${ }^{171}$ It is similar to the contributory negligence provisions allowing courts to apportion liability in cases of negligence, the difference being that the terminology of contributory negligence is not used. ${ }^{172}$ We have noted above that a defendant may contravene the prohibition on misleading or deceptive conduct without negligence. Because of this, courts have suggested that it may be a challenging question to determine the way damages should be apportioned under the CCA. ${ }^{173}$ The assumption underpinning that sort of observation is the apparent incoherence in attempting to compare the parties' culpability in determining the defendant's scope of liability, given that the defendant's negligence is not a condition of liability in the first place. However, as we have

\footnotetext{
170 The application laws of the States and Territories do not contain a provision equivalent to s 137B of the CCA.

${ }^{171}$ See David Wright, 'The Rise of Section 87 Damages?' (2006) 28 Australian Bar Review 88, considering the possibility of claiming damages under s 87 TPA (s 237 ACL) as a way of avoiding the operation of s 82(1B) TPA (s 137C CCA).

172 See, eg, Valcorp Australia Pty Ltd v Angas Securities Limited [2012] FCAFC 22 (9 March 2012) [110] (Jacobson, Siopis and Nicholas JJ), where the defendant's liability under the Act arose from his negligent valuation. It was therefore considered the approach taken in negligence could apply under the Act, accepting that there 'may be cases when some adjustment may need to be made to the application of [that approach], where an apportionment for contributory negligence is made pursuant to [the Act]'. See also Merost Pty Ltd v CPT Custodian Pty Ltd [2014] FCA 97 (19 February 2014) [136]-[147] (North J).

${ }^{173}$ Caffey v Leatt-Hayter [No 3] [2013] WASC 348 (20 September 2013) [503] (Beech J); Valcorp Australia Pty Ltd v Angas Securities Ltd [2012] FCAFC 22 (9 March 2012) [110] (Jacobson, Siopis and Nicholas JJ).
} 
seen, it is arguable that the criteria for establishing breach of the statutory norm can legitimately be uncoupled from the considerations determining the defendant's scope of liability for loss. So it may be that a defendant's failure to take reasonable care may properly inform the application of the particular provision. More important is whether the apportionment provisions themselves reveal any guidance as to the informing criteria for the apportionment process in this context.

The section identifies the claimant's failure to take reasonable care and her share in the 'responsibility' for the loss or damage as the relevant factors. These are fairly broad labels that readily encompass the sorts of objective limiting criteria relevant to negligence and concepts of 'legal causation’ familiar from both negligent misstatement and deceit. This suggests that the enquiry may be directed to matters such as the comparative fault of the parties irrespective of any tortious duty of care, including the risk-taking displayed by plaintiff and defendant, judged against an objective standard of reasonable conduct and, conversely, reasonable reliance. The inquiry into the reasonableness of the plaintiff's reliance on the purportedly misleading conduct would therefore occur at three levels: in characterising the conduct as misleading, in considering the causal nexus between the defendant's conduct and the plaintiff's response for the purposes of accessing a remedy and then in considering whether damages should be reduced on grounds of lack of care by the plaintiff. It is moreover possible that the provisions are sufficiently broad to encompass the concept of mitigation, which is the final issue to which we now turn.

\section{E Mitigation}

In applying the remedial provisions of the ACL concerned with addressing plaintiff loss or damage, courts have only intermittently acknowledged the valuable analytical role that can be played by concepts of mitigation drawn from the common law. In discussing the role of carelessness on the part of plaintiffs, courts have traditionally tended to focus on the irrelevance of contributory negligence and consigned consideration of 'gross negligence' on the part of the plaintiff to the umbrella concept of 'legal' or 'common-sense' causation. ${ }^{174}$ This has generally entailed an all or nothing approach to issues of mitigation, whereby a failure to mitigate may, if unreasonable, be taken to 'break the chain' of causation between the defendant's wrongdoing and the plaintiff's loss. ${ }^{175}$ Nonetheless, courts have occasionally (and we would say properly)

\footnotetext{
${ }^{174}$ Henville v Walker (2001) 206 CLR 459, 468 [13] (Gleeson CJ), 493 [106] (McHugh J); I \& L Securities (2002) 210 CLR 109, 136 [85] (McHugh J), 153-4 [143]-[144] (Kirby J).

175 See above at xxx.
} 
recognised that under the remedial provisions of the consumer law, a plaintiff cannot recover damages for losses that he could reasonably have avoided. ${ }^{176}$ As we have seen, ${ }^{177}$ a defendant's failure to mitigate his loss is relevant to determining his scope of liability under both deceit and negligent misstatement. Similar considerations should bear upon defendant liability under the statute, even prior to the introduction of the apportionment provisions. The policy considerations of reducing economic waste that inform mitigation requirements under general law apply with equal force to statutory liability. Consistently with this view, we have seen that mitigation considerations have consistently influenced defendants' statutory liability through the adoption of the approach taken in deceit to the usual measure of loss in cases involving acquisition of an asset. ${ }^{178}$ Following the introduction of the apportionment provisions, it is clear that whether a plaintiff took reasonable steps to mitigate her loss following breach of the statutory provision may be a relevant issue in determining the scope of defendant liability under the ACL.

\section{CONCLUSION}

It is clearly inappropriate to interpret a statutory prohibition solely by reference to analogous common law concepts; it is the words of the prohibition that must prevail. However, as this paper demonstrates, common law concepts developed in the context of the tort of negligent misstatement can enlighten and inform difficult debates about the scope of statutory liability for misleading or deceptive conduct under the ACL, in a manner which is consistent with the language of the statute and its purpose. The paper has traced how the common law approaches to duty of care in negligent misstatement developed against a background of overlapping standards for assessing the relationship between the parties and their relative fault, and thus for delineating the scope of both the defendant's duty of care and remedial liability. The prohibition on misleading conduct in the $A C L$ does not expressly include any requirement of fault or lack of care in defining liability. Nonetheless, in the context of the statutory prohibition, we see courts similarly engaged in an inquiry into the relationship between the parties and relative expectations of responsibility and care in order to determine the scope of the defendant's liability and in assessing damages. This is appropriate given the nature of the liability issues in question and the words and purpose of the statute. The paper has shown that, while the common law limitations on defendant liability shed considerable light on the nature of courts' reasoning

\footnotetext{
${ }^{176}$ Eg Henjo Investments Pty Ltd v Collins Marrickville Pty Ltd (1998) 39 FCR 546.

177 Above at xxx.

178 See above at $\mathrm{xxx}$.
} 
in this context, it is neither possible nor desirable to draw on isolated components of these limitations without considering their role and fit in the broader setting of the overall common law claim. Likewise, it is necessary to consider closely the proper extent of any common law analogy in the light of the words and purpose of the statute.

The conclusion reached in this paper is that the tort of negligent misstatement does provide a valuable source of analogical reasoning for misleading or deceptive conduct, provided that the caveats noted above are kept firmly in mind. What remains unexplored, and can only be foreshadowed here, is the potential reflexive influence of the statute on the tort. A single example will have to suffice to illustrate this important field for future enquiry. We saw previously that a key concern of negligent misstatement is not to undermine defendants' legitimate pursuit of their commercial interests. It is arguable that what constitutes 'legitimate' commercial behaviour must now be influenced by the statutory norms, including those which proscribe misleading and deceptive conduct. The statute makes clear that it is not legitimate for those who engage in trade and commerce to engage in misleading and deceptive conduct to further their commercial interests, however genuinely or reasonably they may believe themselves entitled to do so. For this reason, it must be doubted that McHugh J's obiter suggestion in Perre $v$ Apand Pty Ltd, ${ }^{179}$ that conduct in breach of s 52 would not be 'illegitimate' for the purposes of negligent misstatement, is correct. Particularly in the light of the High Court of Australia's recent emphasis on the overriding principle of coherence in private law, ${ }^{180}$ there is every reason to think that the statute should exert considerable influence over the norms of commercial conduct that underpin developing torts such as negligent misstatement. In other words, the process may also be reciprocal, with the courts' approach to issues of misleading conduct contrary to the legislation feeding back into the cases dealing with negligent misstatement. Recognition of this can only serve to foster a more coherent and just combination of laws relating to consumer protection.

\footnotetext{
179 (1999) 198 CLR 180, 225 [116].

${ }^{180}$ Miller v Miller (2011) 242 CLR 446; Equuscorp Pty Ltd v Haxton (2012) 246 CLR 498.
} 